\title{
"An Event in Sound"1 Considerations on the Ethical-Aesthetic Traits of the Hermeneutic Phenomenological Text
}

Carina Henriksson

Växjö University, Sweden

Email: carinahenriksson@singnet.com.sg

Tone Saevi

Norwegian Teacher Academy, School of Education

Email: ts@nla.no

\section{Abstract}

In this article, we discuss some of the linguistic features of hermeneutic-phenomenological writing and, in so doing, we point to the close connection between lived experience and the ethical-aesthetic traits of writing the experience. Our exploration starts by contemplating texts written by the so-called Utrecht School. We reflect on their orientation as it has been understood, developed, and advocated by Max van Manen. The literary style of the Utrecht orientation is sometimes misunderstood and questioned. This article aims to explicate why and how hermeneutic phenomenology needs an expressive language to "write the lived experience" rather than to simply write "about" the lived experience. Lived experiences are always past experiences that we try to bring into the present, and so the difference between recollections and memories are discussed in connection to writing the experience. We argue that what is being told and not seen is, metaphorically speaking, an event in sound, which can have ethical and aesthetic virtues of truth and beauty. Lived experiences, whether written as anecdotes or as other kinds of experiential accounts, can shine forth through the use of expressive language. But is this kind of language poetry? Can such an account be regarded as poetic writing? If it is poetic writing, exactly how does it differ from academic writing? Our exploration of questions like these leads us to the tentative conclusion that, as hermeneutic phenomenological researchers, we dwell in the borderland between a "poetic attitude" and a utilitarian writing style. 


\section{Introduction}

In certain quarters, a phenomenologist is held to be "a kind of crystal glazer, a metaphysician or ontologist in the deprecatory sense of the words," (Schutz 1970, p. 53). Others regard phenomenologists as "an esoteric group whose language is not understandable to an outsider and is not worth bothering with" (p. 53). Here we do not, of course, argue in support of these opinions about phenomenological writing; nor will we argue against them. The debate concerning the language deemed suitable by different schools of phenomenology will have to take place outside the scope of this article.

In this article, we endeavor to describe some of the linguistic textures of hermeneuticphenomenological writing and, in so doing, point to the close connection between lived experience and the ethical-aesthetic traits in interpreting and writing the experience.

Our starting point for considering phenomenological writing to be an ethical-aesthetic responsibility of the researcher is Heidegger's (2001) understanding of existence as a poetic ${ }^{2}$ dwelling and Wivel's (1953) postulate that the ethical outlook comes from within, from the poetic outlook. Awareness of the ethical-aesthetic dimension is, of course, of importance to all phenomenological research. However, it becomes even more imperative for researchers who follow the scholars of the Utrecht School and van Manen's orientation to hermeneutic phenomenology, which use an expressive/aesthetic language to turn informants' lived experiences into anecdotes. The dilemma here is how and why we can trust aesthetic language to be ethical.

Our primary interest in phenomenology is methodological, methodical and pragmatic, not philosophical. In this sense, we follow Ricoeur's (1998) declaration that he does not "adhere to the letter of Heidegger's philosophy but shall develop it for my own purposes” (p. 109). Our purpose here is not to tarry in philosophical discourse but to focus on the methodological significance of writing the experience rather than writing about the experience. In so doing, we focus on language and its potential to give expression to the meaning of recollected lived experiences.

This article begins by focusing specifically on the phenomenology of the Utrecht School, particularly as it has been developed as a "research orientation" by Max van Manen (1997b). The scholars who share this orientation (e.g. Buytendijk, Langeveld, and Linschoten) are typically known for at least three things: their choice of everyday, common and situational subjects; their use of experiential material in their texts; and their unconventional writing style. One key notion in the methodology developed by van Manen (van Manen 1989, 1997b) is the anecdote: an experiential description that is carefully crafted by the researcher and that is based on informants' accounts of lived experience. We employ the notion of the anecdote when we explore the linguistic features of writing the experience. When we move from writing the experience to the raw material provided by informants, we employ the term lived-experience description (van Manen, 1997b) interchangeably with experiential accounts. ${ }^{3}$

\section{A “Fine" Human Science}

The scholars of the Utrecht School gained reputations for their evocative and insightful texts on a variety of common human experiences, such as "On Falling Asleep" (Linschoten), "The Meaning of Being Ill” (van den Berg), and "The Psychology of Driving a Car” (van Lennep). ${ }^{4}$ 
What united the original group of like-minded academics was an inclination to integrate the diverse social disciplines and their experiential practices; they were all "sailing under the flag of the personal responsibility and social engagement of the individual human being" (Levering \& van Manen, 2001, p. 278, emphasis in original). However, the methodological underpinnings of their work were kept hidden or in petto. ${ }^{5}$ Thus, the profound existential orientation of the Utrecht School has since been misunderstood as an arcane, impressionistic, and exclusive form of phenomenology. As phenomenological writers, they appear to have simply practiced phenomenology with earnestness and sensitivity, rather than overtly teaching or explicating its substance. The lack of methodological self-awareness of the Utrecht School phenomenology might belong to what Merleau-Ponty (2002) interprets as a characteristic of European phenomenology in general. According to him, phenomenology is a practiced and acknowledged movement that involves a style of thinking and writing before reaching philosophical and methodological self-awareness. Despite the criticism of the Utrecht School, by becoming familiar with their reflective and often beautiful texts, the power of their methodology is almost self-evident. But how did they write like this? Can the skill of beautiful and perceptive writing be acquired through a persevering and sympathetically insightful practice? Our endeavor to understand begins in the world of aesthetics.

\section{Things speak of the beautiful}

The concept of "the beautiful" was once a universal metaphysical concept that had a function in the universal doctrine of being. Even today, the concept of "the beautiful" has significance for contemporary methodology of the human sciences. The original Greek word kalon translates to fine, as in "the fine arts." The adjective fine distinguishes these arts from natural sciences and human sciences. "In fine art the art itself is not beautiful, but is called so because it produces the beautiful," Heidegger claims (2001, p. 35). How does fine art produce what is beautiful? Heidegger demonstrates to us that a piece of art can bring into nearness the nature of a thing-a pair of shoes, for example (van Gogh, 1885). By unveiling the shoe-ness of the shoes, the painting, in its beauty, sets to work the truth about shoes. Under Heidegger's and van Gogh's guidance, we perceive a pair of worn-out shoes, shabby and dirty from daily toil and the worker's contact with water, soil and dust. Before our eyes, these shoes are transformed and we realize that they are not just a pair of shoes but also appear meaningfully as shoes to us. The artist is "a passageway" (Heidegger, 2001, p. 39) to the work, and the work itself guides us to an open space where the authentic being of the shoes is at work. The shoe-ness of the shoes, the "isness" of the thing, is not a representation of a corresponding object that we can verify by matching the depiction correctly to the object depicted.

The is-ness of the thing is not fully accessible to us, but is constantly alternating in its revealing and concealing of itself beyond human control and prediction. As Heidegger notes, "There is much in being that man cannot master. There is but little that comes to be known. What is known remains inexact, what is mastered insecure" (p. 51). In the midst of things, situations and events, there are spaces, openings, and rifts. It is in these gaps of interpretation and understanding that "truth happens" (p. 56), and meaning is disclosed as beauty. Van Gogh's painting is not the expression of an isolated pair of shoes, but an appearance, as Shelley might say, of that which lies beyond perception, as it has been blunted or annihilated through routine. Because we tend to recognize things from their most practical and prominent characteristics, we rarely look closer to see what they really are. 
To the Greeks, to know something was to uncover its being. They called this uncovering aletheia, which can be translated as truth, or literally as unconcealedness (Heidegger, 1998, p. 11). In the fine arts, beauty is exactly this unconcealedness and disclosure. Its appearance is related to the idea of "shining." The verb to shine requires something to shine upon. Thus, to shine means to make that on which the light falls appear. Since this light falls in the realms of both the visible and the intelligible, shining also brings into appearance the meaning of phenomena upon which this light has fallen (Gadamer, 1985). Heidegger (2001) points to the space where beauty occurs as a "lighting" or "clearing." He says, "That which is can only be, as a being, if it stands within and stands out within what is lighted in this clearing” (p. 51). Things appear to us in a bright glade, but simultaneously they withdraw themselves. We pass along the things of the world and we dwell with them as they alternate between self-disclosure and selfconcealment by the light of what they are. "Light of this kind joins its shining to and into the work. This shining, joined in the work is the beautiful. Beauty is one way in which truth occurs as unconcealedness,” says Heidegger (2001, p. 54, italics in original). He continues:

Truth is the unconcealedness of that which is as something that is. Truth is the truth of Being. Beauty does not occur alongside and apart from this truth. When truth sets itself into the work, it appears. Appearance-as this being of truth in the work and as work - is beauty. Thus the beautiful belongs to the advent of truth, truth's taking of its place. (p. 79)

As Heidegger sees it, beauty can be the passage to truth. He objects to any understanding of aesthetics that would reduce it to merely an affective term. A piece of art is not beautiful because it is enjoyable, admirable or precious, but because of its essential ability to let truth happen, which means to reveal "the isness of what is" (2001, p. 79).

\section{Language speaks in the anecdote}

An anecdote speaks to us much in the same way as a good novel or a beautiful poem does. It evokes feelings of recognition, points to experiential possibilities that we have never encountered before, or leads to thoughts whose possibility we were not earlier aware of. When a well-written phenomenological text establishes a relationship with the reader "language is no longer an instrument, no longer a means. It is a manifestation, a revelation of intimate being and of the psychic link which unites us to the world and our fellow men,” (Merleau-Ponty, 2002, p. 196). In the hands of a talented phenomenologist, the meaning of words is given a new twist. Or rather, as Heidegger notes, a phenomenologist has learned "to live in the speaking of language" (2001, p. 207). Much like Heidegger's own evocative response to Georg Trakl’s poem $A$ Winter Evening, the intention of a phenomenologist is to have the reader receive and respond to the otherwise concealed meaning of the lived experience which can be evoked in the honed anecdote. Van Manen, like Heidegger, makes substantial use of experiential material-such as literature and other artistic work - in order "to refer beyond the realm of what can be said clearly and distinctly [...] and to make present a meaning which we are unable to express clearly in any other way" (Kockelmans, 1987, p. ix). To listen and respond to the things of the world through language, to let language itself speak is, according to Heidegger (2001), the only way that human beings can truly say something. By listening to the speaking of the things of the world, the vocatio of a text, we feel addressed by the experience. The vocation, or call, of a text is sensed as an implicit, felt 
understanding that is non-cognitive as well as cognitive, sensed as well as reflected.

Language, seen not primarily as expression, utterance or action (Heidegger, 2001) but, rather, as a disruption or a peal of the stillness of things, can be both evocatively inventive as well as commonly accessible. In reflecting on the phenomenological text, van Manen (1997a) identifies five vocative qualities, which strikingly resemble the fictional devices of the novelist. His methodological shift of focus, from content to form and beyond, shows that content and form are indivisible for phenomenological writing: "When we turn from thematic meaning to expressive meaning then the question we ask turns from 'what does the text speak about?' to 'how does the text speak?'” (van Manen, 1997a, p. 345). How the text speaks is a matter of letting the mantic dimensions of the language come to expression, a perspective also noticed by Heidegger, Merleau-Ponty and Wittgenstein. The mantic-expressive language first and foremost speaks in the concreteness, the addressiveness, the embeddedness of meaning, and by the transformative qualities of the text. The evocative dimensions belong to our common day-to-day language and might be so close to us in speech and reading that we miss what they say. Heidegger notes, "Everyday language is a forgotten and therefore used-up poem, from which there hardly resounds a call any longer” (2001, p. 205). The experiential account brings a possible human experience into nearness by mediating the tension between the particular and the universal of this experience. As they occur in phenomenological writing, anecdotes are, thus, not mere illustrations to embellish an otherwise boring text. The anecdote can be understood as "a methodological device in human science to make comprehensible some notion that easily eludes us" (van Manen, 1997b, p. 116). When the anecdote tells us something about a particular experience, a unique person, or an individual life, it also reveals something universal. "And vice versa, at the hand of an anecdote fundamental insights or truths are tested for their value in the contingent world of everyday experience” (p. 120).

An open, accessible style of writing and way of relating experiences harmonizes with phenomenological philosophy and phenomenological writing. Accordingly, this style of scientific writing is based on conversations and dialogues with others, with oneself as an author, and with language itself because "its speaking speaks for us in what has been spoken" (Heidegger, 2001, p. 207). The ideal of phenomenological writing is the literary prose style, the vague and the equivocal, the quote and the collage, the question and the provocation, the void and the vision (Cooley, 1981, our translation). No matter how much effort we put into describing the experience and interpreting its possible meaning, phenomenological texts can never be heard as completed symphonies; well-conducted they may be, but they are eternally bound to be etudes. There will always be another, alternative interpretation. In that sense, phenomenological texts are, simultaneously, conversations that open into the future, and ongoing dialogues about the ethical-aesthetic dimensions of the texts.

\section{How it speaks}

Roland Barthes (1981) once said that a text needs to have punctum; it needs to have a point. Phenomenological texts can make something new; they can invent perspectives, connections, compositions, thoughts that have not been presented in that way before. The phenomenological text aims to present a difference (Heidegger, 2001) to bring forth something by discerning it from the rest, to present something unique or previously unthought-of. It seeks to bring something forth, to bring something into light, to let something shine, or as Barthes (1981) notices, to point out the particular meaning of something and establish a punctum. A snapshot, he 
says, becomes a photograph when it has punctum. An unfocused, random "snap” cannot make sense on its own since it does not speak to us. Instead, the photographer speaks to us through his or her engagement in the act of creating the photograph. A snapshot cannot make sense on its own since it does not speak to us-the photographer does. It needs the photographer to explain what it portrays.

No image presents the original. Although it is always a representation, it has analogous qualities. In the case of a photograph or a snapshot, it might be a perfect analogon. There is however, a profound difference between a snapshot and a photograph with regards to what they tell and the language with which it is said. While the familiarity and immediate identification of an event in a snapshot creates a recognizable atmosphere that we may approve by experience, a photo has a stranger, more intriguing, perhaps even hostile influence. A snapshot is fixed in place and time, and depicts a particular moment. We may wonder about the particular content of the moment of a snapshot, but nothing emerges from the picture that brings forth a counter-image or a sense of a deeper questioning. A snapshot points to itself. Its lack of uniqueness might lead to confusion with other snapshots, and its reality is analogous in a corresponding way to the truth of the image.

A photograph has punctum insofar as it pricks us, touches us, disturbs us, moves us, and addresses us. A photograph speaks for itself while the photographer is silent. Barthes (1981) notes that a photograph is "a message without a code... the photographic message is a continuous message” (p. 196). The photograph with punctum is not a correct and complete analog for reality, but rather a transformative image that speaks beyond the reality captured in it. More than a mere representation of the world "as it is" like a random snapshot, a photograph causes the viewer to question its existential meaning. A photo with punctum prompts us to wonder and, at the same time, involves us in self-reflection. According to Heidegger (2001), artwork, like photos, can "place us in that lighted realm in which every being stands for us and from which it withdraws" (p. 51). The meaning of the photograph is continuous, open, inexhaustible, and not immediately accessible as a totality to sensation and thought. The photograph, unlike the random snapshot, is a not transparent or translucent representation, but has a transformative effect on the viewer.

Quotations from a qualitative interview may fall somewhere in between the random snapshot and the photograph with punctum: It can require some interpretation by the reader, but generally does not simply work on its own to prompt the reader to self-reflection or wonder. An anecdote in phenomenological writing, on the other hand, is meant to touch us, to address us. It makes contact with something inside us and, if well written, imbues us with wonder. A compelling anecdote has the duality of pre-reflexivity and interpretation; "it simultaneously pulls us in but then prompts us to reflect” (van Manen, 1997b, p. 121). The compelling anecdote renders possibilities for the researcher to unveil themes in an experience since the anecdote is not about the experience. For the involved reader, it is the prereflective experience, the experience as lived through.

The scholars of the Utrecht School did not hesitate to turn to the world of aesthetics in their attempt to describe human experiences. They were inspired by poetry, literature, music and art in their scientific texts. It is striking how their texts, by combining the rigor of science and the beauty of poetry, evoke a pathic sense of grasping the described phenomena. Decades before Roland Barthes (1989) talked about integral writing as a sort of holistic writing - the merging of more traditional academic language and the language of literature-the scholars of the Utrecht School were already practising it. They already knew and adhered to the idea that: 
[Human] science will become literature, insofar as literature-subject, moreover, to a growing collapse of traditional genres (poem, narrative, criticism, essay) — is already, has always been, science; for what the human sciences are discovering today, in whatever realm: sociological, psychological, psychiatric, linguistic, etc., literature has always known; the difference is that literature has not said what it knows, it has written it. (Barthes, 1989, p. 10)

For that reason, we do not hesitate to call the phenomenology of the Utrecht School, and the development of the orientation, a fine human science. By "linking the poetic word with everyday speech as an intensification of the latter” (Gadamer, 1985, p. 470), hermeneutic phenomenology lets us see the phenomenon as it shines forth. By interpreting insights, phenomenology serves as a deeper understanding of meanings. Although phenomenological inquiry, as experience itself, lacks fulfilment (Kuhns, 1970, p. 68), a systematic and intersubjective methodological phenomenology concerns itself with the same questions, and also structures experience in the same way as art.

\section{The light of subjectivity}

An evocative text shines in itself and, simultaneously, it shines upon the phenomenon it evokes; it brings the phenomenon out of concealment. Luijpen notes, "Unconcealedness requires a certain 'light' ... This 'light' is the 'light' of man's subjectivity” (1960, p. 137-138). Phenomenologists have, from time to time, been upbraided for treating truth as being merely subjective and relative. However, to the phenomenologist, the truth is not primarily to be found in the normative elements of justice and systems, but is intertwined in the relational existence of human beings. By living one's life and by reflecting on existence, the human being brings it out of concealedness, merely by living its intentional meaning. In accordance with Heidegger, Luijpen (1960) names our conscious existence the lumen naturale, or the natural light. It constitutes the very nature of persons, the human being as "a being unveiled" (p. 143). This lumen naturale, called logos by the Greek, translated by Gadamer as both reflection and language, is the aletheia that takes being out of the concealedness of human existence (Heidegger, 1962). In the natural sciences, person and object are kept at a distance from each other, and the world is a world upon which human beings act. In phenomenology the two melt into each other (Merleau-Ponty 1997). In a profound way, the meaning of the world is inseparable from the things of the world, and also from the meaning of being a human. Language is not a device that we create to name the world according to our own sweet will, but rather something we take part in, something that is ahead of each subject - the world in which the subject unfolds. Derrida (1992) notes that words are more than simply information, communication, or disclosure. Language is testifying, witnessing. What is said, orally or written has a meaning beyond itself, because it speaks of "what I will tell”. Language is a testimony of my point of view, my understanding, my interpretation and, ultimately, of whom I am. My language may, to some extent, be experienced as subjective, and yet it is still part of the human community constituted by a linguistic meaning community, and as such, it interprets both subjective and intersubjective meaning.

Dreyfus (1991) maintains that the human reflective attitude is always secondary and derivative, while the immediate subjective is primary. Merleau-Ponty (2002) notes that we cannot separate ourselves from the world, but are a part of the world which we understand and 
are related to. He says, "For we have the experience of ourselves, of that consciousness which we are, and it is on the basis of this experience that all linguistic connotations are assessed, and precisely through it that language comes to have any meaning at all for us” (pp. xvi-xvii). The experience has meaning for us and we express that meaning in language. Merleau-Ponty urges us to trust our experience of the world, and the impossibility of a catatonic, in order to avoid skepticism. In fact, we might too easily come to trust intellectual and scientific knowledge, and begin to distrust the world as reveals itself to us in language and by its very existence. "We must not, therefore, wonder whether we really perceive a world, we must instead say: the world is what we perceive" (p. xviii). We share a lifeworld that is intersubjective and relate to this mutual lifeworld in our constant experiential interpretation of meaning.

The texts written by the Utrecht School could be described as distilled, refined accounts of lived experiences, and as such, they shine forth by the light of subjectivity. The mere use of words such as beauty, light, and shine points us to the intrinsic and enigmatic relation between the experience and the expression of the same, and between description and interpretation, all of which are embedded in the elusiveness of language. Gadamer (2002) sees a connection between the concept of intuition and that of vividness, since intuition (as an aesthetic problem) cannot be understood merely from an epistemological standpoint. Rather it is related to the "free" play of imagination and cognition. Gadamer (2002) asserts:

It is here, in the use of language, in rhetoric and literature, that the concept "vivid" is truly at home: namely, as a special quality of description and narration such that we see "before us", so to speak, what is not as such seen, but only told. That is clearly an aesthetic quality. (p. 158)

What is being told and is not seen is an event in sound. Moreover, such an event has the ethicaesthetic virtues of both beauty and truth; the telling that is this event unveils qualities that display the scene freely before us, vividly addressing our intellect as well as our senses and sensations. As phenomenologists, who wish to show, describe, and understand human experiences, we dwell in the borderland between vivid descriptions, free imagination, and intellectual intuition. Phenomenology and art seem to share experiential structures, (Kuhns 1970) and might be seen to reinforce one another, rather than being "separate in scholarship" (Kuhns, 1970, p. 53). Phenomenology and art share the desire to present and represent the aesthetic and truth of the events of the world. Kuhns notes that "taking philosophical accounts together with literary art allows us to entertain different approaches to the same kind of experience. Philosophy argues its possibility; literary art offers it whole" (p. 81). If this is indeed the case, phenomenological writing might lead beyond the solely aesthetic stand of performance indicated by modernity, toward an ethic-aesthetic textual practice that, at its best, is beautiful as well as morally bound.

\section{Memories and recollections}

Speaking of the human sciences, Barthes (1989) writes, "Science speaks itself; literature writes itself; science is led by the voice, literature follows the hand; it is not the same body, and hence the same desire, which is behind the one and the other” (p. 5). For hermeneutic phenomenology, it $i s$ the same desire. Through the hand, we wish to give voice to that which experience speaks of: memories of moments lived through. One of Sartre's projects is relevant in this area: When one is inside an event, one is not thinking of it. To live a story and to tell a story are different 
experiences. "One can live or tell; not both at once” (Murdoch, 1953, p. 11). Thus, a telling of lived events is a recalling of the lived in the shape of a memory. As a result, phenomenological telling is retrospective, looking beyond or behind what is currently at hand, distinguishing between appearance and essence, facticities and facts.

Facts, van den Berg (1961) holds, are the "skeleton of the past" and to recollect facts of the past is not to retrieve memories: "We know that the war began on the 10th of May, 1940. But this knowing is still not a memory; we are only remembering a fact, nothing else” (p. 33). The invasion of the Netherlands is a fact duly proved and archived by media, history books and other historical documents. History (Die Historie), Heidegger claims (1962), is what actually happened. The story (Die Geschichte), on the other hand, is what happened to the singular subject, the meaningful and lived-through experience of the subject. Recollection of the invasion of the Netherlands as a historical fact is different from the experiential accounts of the day of the invasion. Thus, actual memories of the day, May 10th, 1940, are another matter altogether. ${ }^{6}$ We could not do without the day itself, van den Berg (1961) says,

The day as it began, the warm day in spring with clear blue sky and whirring metal planes in it; the early hour and all the pyjama-clad people looking at the sky. We need all the attributes of the event, we can hardly omit even one of them if we are to tempt the day to show itself. And then, suddenly, there it is, the day, just as it all happened; thousands of impressions are there at the same time, unabridged and full of meaning, still nameless. And before they get a name, they have sunk back in that immense grave called the past. (p. 33-34)

So what do van den Berg's thoughts on recalling memories mean for the gathering of experiential accounts? First, the problem with lived experiences is that they often hide deep down in our memory where they sometimes stubbornly resist our struggle to bring them to light so we can reflect on and articulate them (Henriksson, 2009). A memory can be as elusive as the Cheshire cat; all we see is its teasing smile. However, van den Berg holds that "the past is not unavailable to us and we come to realize that when, in precious moments, the past "jumps or flies at us in a smell or a sound'” (van den Berg, 1961, p. 34). He goes on to say that the past is always ready for us, "only a word is needed, a chord, a small constellation of things, something incidental, whatever it is. It seems as though the past can only come to us through a back entrance; the front door is closed" (p. 34). How do we find the back entrance to memories of the past? Is there a key somewhere? Can we make memories jump or fly at us?

\section{The roundness of the memory}

The past is already ready for us; a back entrance is half open, only a particular chord needs to vibrate for a memory to flash back on us. In her novel Sartre Romantic Rationalist, Murdoch (1953) attends to the semblance of the novelist and the phenomenologist to speak in ways that may echo the tone of evocative and vivid memories:

The novelist proper is, in his way, a sort of phenomenologist. He has always implicitly understood, what the philosopher has grasped less clearly, that human reason is not a single unitary gadget the nature of which could be discovered once for all. The novelist has had his eye fixed in what we do, and not on what we 
ought to do or must be presumed to do. He has as a natural gift that blessed freedom from rationalism which the academic thinker achieves, if at all, by a precarious discipline. He has always been, what the very latest philosophers claim to be, a describer rather than an explainer; and in consequence he has often anticipated the philosopher's discoveries. (p. 8)

Being a phenomenological describer and a hermeneutic interpreter-both aspects being the leading desire of the Utrecht School phenomenologist - clearly influences the phenomenological language and the textual expression of which we are depending to somehow approach the experience as it was lived through in the past. Human experience, not being a unitary process to be experientially accomplished and fulfilled, nevertheless is experientially concentrated and focused as an instant entity. The human experience is not the observant observation of things or events, but the immediate lived thoroughness of a moment before it is reflected. The experience is from the inside, and as Bachelard (1994) notes, "devoid of all exterior features, being cannot be otherwise than round" (p. 234). Being isolated in a particular momentous description the memorable moment of young Proust is an entity that is concentrated upon itself, and thus, in Bachelardian terms becomes spherical, centralized, rounded, a unity of meaning.

One day in winter, on my return home, my mother, seeing that I was cold, offered me some tea, a thing I did not ordinarily take. I declined at first, and then, for no particular reason, changed my mind. She sent for one of those squat, plump little cakes called "petites madeleines," which look as though they had been moulded in the fluted valve of a scallop shell. And soon, mechanically, dispirited after a dreary day with the prospect of a depressing morrow, I raised to my lips a spoonful of the tea in which I had soaked a morsel of the cake. No sooner had the warm liquid mixed with the crumbs touched my palate than a shudder ran through me and I stopped, intent upon the something isolated, detached, with no suggestion of its origin. ... this new sensation having had on me the effect which love has of filling me with a precious essence; or rather this essence was not in me it was me. I had ceased now to feel mediocre, contingent, mortal. Whence could it have come to me, this all-powerful joy? I sensed that it was connected with the taste of the tea and the cake, but that it infinitely transcended those savours, could, no, indeed, be of the same nature. Whence did it come? What did it mean? How could I seize and apprehend it? (Proust, 1970, p. 48)

The now-famous paragraph from Proust's In Search of Lost Time, illustrates how memories are able to jump or fly at us, even beyond our "wanting and doing" (Gadamer, 1985, p. xxviii). The taste of the Madeleine cake did not just stir a memory, "this essence was not in me it was me," Proust writes. The memory, which came through what van den Berg calls "a back entrance," did not come as a temporal single fact or recollection of a time past, it came as a corporeal, spatial, relational and concentrated lived experience which pervaded his whole being. The essence of the memory was me, Proust says. It is exactly this essence (as meaning) of a memory that is the target for hermeneutic phenomenological inquiry, this is what we, as researchers, try to "seize and apprehend" and this is also, ironically, what we are doomed to fail at. We are always too late to catch the pre-reflective meaning of an experience as lived in the past. Yet, we continue to try.

Not just our senses including smell, taste, and sound, but also objects could open the back entrance to memories and, thus, function as mediators between the past and present. Previously, 
Socrates argued that both objects and people are mediators of recollections. Like Proust's madeleine cake, objects can cause us stumble on memories accidentally.

And what is the feeling of lovers when they recognize a lyre, or a garment, or anything else which the beloved has been in the habit of using? Do not they, from knowing the lyre, form in the mind's eye an image of the youth to whom the lyre belongs? And this is recollection: and in the same way anyone who sees Simmias may remember Cebes; and there are endless other things of the same nature. (Plato, 1973, p. 506)

The word recollection is etymologically related to the word remember, meaning recall to mind, be mindful of. The word also has the meaning "to evoke memories." Recollection, Plato says, is "a process of recovering that which has been forgotten through time and inattention" (p. 506). So, if we are mindful of our recollections, we might find that memories jump or fly at us as van den Berg (1961) holds. To memorize has the original meaning of "commit to writing" and that is precisely the task of phenomenology; we ask our informants to "memorize," to recall a specific moment, a moment that we then try to capture in writing.

\section{Narrating the past in the present}

Our memory is, however, more than a mental force that enables us to recall personal experiences. The memory is, in fact, what "makes shared experience possible" which allows us to "participate with other minds in an enlarged awareness" (Kuhns, 1970, p. 107). Recollections, as Socrates describes them, might turn into memories by the sight of something that we associate with something else-for example, people, objects, places, feelings-and help us open up the intersubjective space of shared experience:

Sometime during the evening one of the children found an old photo album and started to ask questions about people who she did not recognize in the photos. My sister-in-law walked over to help identify people. Suddenly she exclaimed, "Look! The old blue bucket!" Suddenly, the child with the photo album found herself surrounded by adult relatives. "We used to carry the fish from the boat to Aunt Amelia's house in it. Remember how it reeked of fish?"

"Oh yes, we kept it in the garden shed because of the smell!"

"Aunt Amelia really hated when we brought her eels, especially if they were small!"

"Still, her pickled eel was one of the best in the village...."More and more relatives gathered around the table to join in the conversation. "Didn't we use that bucket when we bricked your garage, Andy?"

"Yes, we did! I had forgotten that. Remember when Marge brought us coffee and you fell of the ladder when you tried to reach the mug! God, how we laughed!"

"Who bought Aunt Amelia's house when she died?

"Wasn't it the son of the next door neighbor?"

"Yes, maybe it was."

"Whatever happened to the bucket? Do you think it is still in the garden shed?" 


\section{"Maybe the new owners use it now...."}

The blue bucket was not just a conversation piece; it became a mediator of past events and it evoked memories of people, places, and moods. The Past was no longer the past that had been, but a past alive in the Now. Undoubtedly, several lived experiences were recollected and turned into memories that evening. Perhaps these lived experiences were also told, shared and interpreted.

Although memories can be happy, they might also be sorrowful and wistful, something we need to keep in mind as researchers. What memories and emotions do we awake in the informants when we ask them to recall a specific moment? Neither the informant nor the researcher could know the forces that might be let loose when we ask for a lived-experience description; embodied memories could be dormant or suppressed but the body has its own way of dealing with memories.

Perhaps the body has its own memory system, like the invisible meridian lines those Chinese acupuncturists always talk about ... Maybe the pain of memory is encoded into our marrow and each remembered grievance swims in our bloodstream like a hard, black pebble ... perhaps the body is this hypersensitive, revengeful entity, a ledger book, a warehouse of remembered slights and cruelties. (Umrigar, 2007, pp. 103-104)

As researchers we need to tread lightly both when we borrow other peoples' lived experiences and when we set out to write and interpret these experiences. In addition, as the different steps of the reduction urges us, we need to keep a close eye on our own lived experiences of the phenomenon under investigation. We, too, have bodies with their own knowledge and memories, bodies which may lead us astray when we try to describe and understand possible meanings of the phenomenon. If memory and recollections are etymologically connected to the act of "committing to writing," then the mere act of writing down the memory would result in a "Eureka!" But, to catch that which "shines forth" in a phenomenon with words is, at times, as impossible as trying to catch a sun beam. We may find that we "see the words fly about the room in all directions" (Abrams, 1953, p. 216). Yet, we hold with van Manen (1997b) that writing is the method of coming to understand the meaning in lived experience.

\section{Writing the experience}

In hermeneutic phenomenology, there is a compelling connection between reflection on the meaning of experiential accounts and the writing process. A phenomenological text is not so much a traditional research report, but a wilful wandering into a more profound understanding of the taken-for-granted; the text aims to be a questioning experience for the reader (as well as the writer). Gadamer, by reference to Vico, the Italian $18^{\text {th }}$ century philosopher, points to the old truth of common sense, and the classic human ideal of wisdom as a mode of knowledge: "Talking well" (eu legein) has always two meanings; it is not merely a rhetorical ideal. It also means saying the right thing, i.e. the truth, and is not just the art of speaking or saying whatsoever well. (Gadamer, 1985, p. 19) 
The truth based on common sense and wisdom is a knowledge not based on argumentation, but is a practical knowledge, phronesis, that shows itself to us as obvious and trustworthy. Aristotle (384-322 B.C.E) considered phronesis to be an intellectual virtue and a "determination of moral being, which cannot exist without the totality of the 'ethical virtues,' which in turn cannot exist without it” (Gadamer, 1985, p. 22).

The vita memoriae, the truth in "convincing examples as only history can offer them" (Gadamer, 1985, p. 23) is, to Aristotle, a moral knowledge that might also be operative in recollected lived-experience descriptions. Gadamer suggests that Aristotle's digging into the epistemological significance of the senses was "intended ultimately to correct the exaggeration of philosophical speculation” (p. 25). The buffer effect of the credible lived example against abstract, conceptual knowledge is relevant in contemporary phenomenology as well. The lived experience is a "living feeling" (p. 57), is "the unit of what is given" (p. 59) and has an "inner relation to life” (p. 61)—qualities that makes the lived experience a meaningful rounded whole. A lived experience is "taken out of the continuity of life and at the same time related to the whole of one's life” (p. 62). The phenomenologically meaningful lived example is distinguished from the rest of life's web by being told, written, honed and increasingly made sense of. And at the same time, the lived example inserts itself in life and adds sense to the self and the life of the person.

In research, however, we do not ask our informants to sit down and try to recall just any lived experience. We want them to share with us, in speech or in writing, a memory of a specific moment when they experienced something that something being a subject singled out by the researcher. Once the memory of the lived experience has surfaced we face another predicament: How is it best described? What words do we use to name the unabridged and meaningful memory?

\section{"An Event in Sound"}

In her book on Sartre, Murdoch (1953) argues that the difference between poem and prose is not found in their aesthetic properties - imagery, language, word-order, thought, movement, or argument. "What makes a poem separate is not just the mode of language-using of which it is an instance, but the quality and integrity of the poetic thought of which it is an incarnation” (p. 72). The distinction is not between poetry and prose, she argues, but between substance and the lack of substance, between "disciplined aesthetic uses" and "formless non-aesthetic uses of language" (p. 72). The poetic reflection tunes us in toward the inner disturbance and interference of existence and "directs attention to the things of the world, [it] alters courses of action, [it] arouses feelings and conveys information” (p. 73). Addressing the description below, one may wonder if the "world changes first and pulls language after it, or [if] a new awareness of language suddenly makes us see the world differently" (p. 28).

After just a few months in second grade, our son announced at dinner, "I hate writing!" Since I consider him a verbal little person, I was surprised at his outbreak.

"What's so terrible about writing? Isn't it nice to see your thoughts on paper?"

"Mum, it takes forever to put words into sentences and sentences into paragraphs! And Mrs. Peterson wants me to write about our winter holidays. It's 
so tedious!"

"Well, why don't you try to express your thoughts in a poem, then?"

"What's a poem, Mum?"

How much would a seven-year-old understand about the difference between prose and poetry? I tried to explain in as uncomplicated a manner as possible.

"You see, when you write a story you need to put all the words you use in a certain position, you cannot just pile them up. You need to get the order of the words right otherwise they don't make sense. Now, in a poem you don't necessarily have to do that. A poem is meant to leave empty spaces, and these spaces are for the reader to fill with imaginations of their own."

My son looked a bit puzzled, but silently finished his meal and then disappeared into his room. Half an hour later he was still in his room, door closed. My knock on the door was answered by a muffled, "Who is it?"

"It's Mum. May I come in?"

"Uhuh..."He is curled up by his desk, his posture indicating concentration. On the floor around him, heaps of papers are floating. On his desk, yet another sheet of paper is the target for his profound attention.

"What's all this?"

"It's poems, Mum."

"May I have a look?"

"Sure."

I pick one paper randomly from the floor. While I read the poem, my son stops writing, lifts his head, and listens as I pronounce his words and give voice to his experiences:

"Winter night

Wolves howling to the moon

Fireworks!!!! Boom, boom!

Cold stars

Winter Night

Happy new year!"

I pick up sheet after sheet from the floor. An army of poems are marching over the pages; steadfast and unwavering they carry variations on the same theme across the pages: winter nights. "These are beautiful poems!"

"Yes, I know, he beams. This is real writing, Mum!" Since that day he has notat least to my knowledge-written any more poems, but neither has he complained about the agonizing act of writing. The very few times he lets me read anything he has written in school, I am amazed by his vocabulary, his thoughtfulness, and the eloquence of his texts.

What did this young boy experience while he was producing all of these poems which described his feelings on New Year's Eve? Did he relive the winter nights through the words? Perhaps he met himself as a person for the first time, a human being standing in the midst of fireworks and wolves' howling, hailing the words which were suddenly there for him? Perhaps, that evening, he found what Barthes (1989) calls "the Eros of language" (p. 9). "This is real writing, Mum!" he said. What is real writing? Is there fake writing too? Judging from the comment, experientially there is. What, then, is the difference between real and fake writing in human science texts? How do we, the writers-researchers-interpreters, do justice to the meaning of the 
lived-experience descriptions? What language do we use?

\section{Poetic Writing or Writing Poetry?}

The adjective expressive has as synonyms eloquent, empathic, lively, lyrical, meaningful, poignant, revealing, strong, thoughtful, vivid - all of which signal that the role of the researcher in hermeneutic phenomenology is not that of a mere writer of a scientific report. In addition to analytic, interpretive, and methodological skills, we need a skill involving semantics, the sense of the value of words, and an awareness of how fringes and halos surround words and expressions. But does that mean that phenomenologists are also poets? Before we continue, some semantic distinctions are necessary.

The word poesie has its roots in the Greek word poiēsis which means making, fabrication, poetry, and poem. But poesie also has a narrower meaning than the original poiessis that applies especially to writing in verse as opposed to prose. Heidegger's notion of Dichtung has its etymological roots in the Latin word dictare, meaning to invent, to write, or to compose verses. This notion has a wider meaning than poesie and applies to all creative writing. Heidegger uses Dichtung in a narrow and in a broad sense: in the narrow sense it refers to poetry; in the broad sense it refers to the original meaning of inventing, writing, and composing (Inwood, 2006). For scholars within the tradition of the Utrecht School, it is this latter meaning of the Heideggerian Dichtung that establishes language as poetic and expressive. For Heidegger (2001), there is also a close unsurpassable relationship between poetic language and thinking:

When thought's courage stems from the bidding of Being, then destiny's language thrives.

As soon as we have the thing before our eyes, and in our hearts an ear for the word, thinking prospers.

Few are experienced enough in the difference between an object of scholarship and a matter of thought.

If in thinking there were already adversaries and not mere opponents, then thinking's case would be more auspicious. (p. 5)

The phenomenological effort of writing ingeniously, the endeavor to initiate or originate a resonant language rich with experiential meaning, comes from the way we dwell with the things of the world. When a phenomenological text speaks to us, like a poem or a novel does, it is because it evokes in us recognition or thoughts which are new and at the same time conversant. Heidegger's (2001) persistent experience that “language speaks” (p. 188) somehow puts the human being in a position where he or she becomes a witness to the act of writing. Language calls things into nearness and each thing presents and represents a whole world of meaning. The 
phenomenologist is the dative of life and the world of things, the who to whom something is given. $^{7}$ The phenomenologist as well admits with Heidegger (2001) that "the world grants to things their presence. Things bear world. World grants things” (p. 199). The intimate relation among things, world, human being and expression, is an incisive experiential proximity, a genuine but neglected inseparability. Experiential accounts collected from fictional literature, novels, poetry, or from the world of aesthetics, art, films, or music may assist in presenting and describing the richness and subtleties of phenomena in human life. A phenomenological text combines "the power of philosophic or systematic discourse with the power of literary or poetic language ... a tension between the pre-reflective and reflective pulls of language (van Manen, 1997b, p. 121).

Literature and poetry are frequently evocative mediators for a deeper understanding of human experiences. Just think of how Shakespeare, in Macbeth, brilliantly underscores power corruption, how Euripides, in Medea, illustrates the fury of a woman scorned, and how Strindberg, in The Pelican, shows the lifelong deception and the collapse of a family. It is, though, important to bear in mind that "poems and novels do not 'prove' anything. But both can be enormously helpful in bringing certain phenomena closer to us and thus in making us 'understand' them, helping us to understand ourselves and the world in which we live" (Kockelmans, 1987, p. viii-ix).

\section{Science and literature}

For a long time, humans have made a clear distinction between science (natural as well as human) and literature. Science has been ascribed its own characteristics distinctly apart from those of literature. The differences-but also the similarities-become decidedly noticeable when we look at the role of language. In science and in literature language does not constitute itself in the same way.

For the scientist who wishes to write up his report, content tends to precede form. Only when the content is clearly stated does language enter the report. Language becomes a tool, an instrument, which the scientist wishes to make as neutral as possible. But language as a neutral device is nothing but a mere illusion, a self-deception on behalf of the scientist. Writing is not merely a cognitive, pragmatic act. "Language itself, however, has something speculative about it ... as the realization of meaning, as the event of speech, of mediation, of coming to an understanding” (Gadamer, 1985, p. 469). Writing could be liberating, inspirational; in writing the words construct, confirm - and challenge-your world. For the writer, though, language never pre-exists social, emotional, or scientific reality. "No, language is the being of literature, its very world: all literature is contained in the act of writing, and no longer in that of 'thinking', (Gadamer, 1976, pp. 4-5). It would seem that Gadamer crosses swords with Heidegger (2001), who sees a close link between poetry and thinking. However, Gadamer (2002) also argues, when he addresses the difference between what he calls "intentional words" and the words of poetic language, that "there are transitional cases that stand between poetically articulated language on the one hand and the purely intentional word on the other" (p. 67).

What is the difference between Johan's voice in Strindberg's The Maid's Son, when he describes his lived experiences of school, and the voice of a student who does not feel recognized by his or her teacher in a qualitative, scientific study (e.g., Henriksson, 2008; Saevi, 2003)? What is the difference between the voice of a sick, bed-ridden woman in Axelsson's 
novel The April Witch and the experience of bed-ridden patients, who are being fed in a scientific study (e.g., Martinsen, Harder \& Biering-Sorensen, 2008)?

One could argue that a difference is that literature speaks to our senses while science speaks to our intellect. Or one could argue that the difference is a question of validation. Although a novel or a poem can touch us, or even transform us, it could be shrugged off by thinking "it's just make-believe,” something not true, not valid. In contrast, a scientific report is subject to serious scrutiny by academic peers, referees, or supervisors. Thus, literature and science deal with different realities; a novel is ultimately the subjective fantasy of one person, while science presents us with the ultimate objective matter-of-fact truth. Yet another difference, we hold, is the usability of the different kinds of texts: what pragmatic use do they have? Scientific reports explicitly or implicitly suggest a solution to a problem; the text has, or points out, The Answer. A novel or a poem, on the other hand, is likely to evoke reflection, to point to questions and not to point out answers. Furthermore, when we read scientific reports and literature, we do it with different attitudes towards the text. When I sit down to read a novel, there are some taken-forgranted features at work: It is not real, but fantasy. Although the author may vividly describe persons, actions, and milieu, it is in $m y$ mind that the images are born, there is no external verification of what the text says. Gadamer (2002) shows this concept using Dostoevsky's novel The Brothers Karamazov as an example.

The staircase that Smerdjakov falls down plays a major role in the story. Everyone who has read the book will remember this scene and will "know" exactly what the staircase looks like. Not one of us has exactly the same image of it and yet we all believe that we see it quite vividly. It would be absurd to ask what the staircase “intended” by Dostoevsky really looked like. (p. 111)

No, we do not want to see the "intended" staircase. We demand that authors of fiction present us with words, which we, the readers, can turn into images that are ours, and ours alone. At the same time, our images can be curiously shared with other readers. What happens if the author of a novel imposes the "intended" upon us?

In her novel The Shape of Snakes, Minette Walters (2000) portrays a black woman in a white community, "Mad Annie", who suffers from Tourette's syndrome and alcoholism. Walters uses different literary techniques (handwritten letters, newspaper clippings etc.). Although these techniques are somewhat atypical for fiction, they are not uncommon, and as readers we accept them as the poetic freedom of the writer. What makes Walter's novel stand out, is something else altogether. Eighty pages in, when the readers are well acquainted with the characters, their thoughts, their surroundings, and how they are related to each other, when the readers have formed images of the lives and faces described, Walters defaces these personal images by forcing the "intended" upon us. She presents photos of the main characters. In so doing, Walters manipulates a world, which we, up until the moment we first lay eyes on the photos, thought was ours. As readers, our original attitude or intention toward the text is thwarted by the author's intention. There is a loss of equilibrium as Walters, through the photos, declares our images "wrong" or invalid. Suddenly, there are no clear lines between fiction and what is (allegedly) real, and we lose our foothold and our "mindhold," our attitude. We simply cannot figure out what attitude to adopt toward this text. Is it fiction? Is it real? How do we receive the message of the book? We seem to adopt different attitudes depending on whether something actually happened or whether it could have happened. Is Walter's book true writing or fake writing? We feel an urge to know. How else can we know how to relate to the content of the book? 
In a similar way, we tend to separate science from literature, which shows that we are still burdened by the Cartesian dualistic heritage; some things belong to the brain, some things to the mind. And yet, we are not fully able to understand how perception interacts with thought or our bodily senses. This compartmentalization of spheres disregards the Husserlian belief that science, too, is a part of our lifeworld. Our lifeworld is not compartmentalized, fragmentized; it is a complex whole, as we live, interact, speak-and write. "Today we have often to labor to regain the awareness that the word is still always at root the spoken word. Early man had no such problem: he felt the word, even when written, as primarily an event in sound...” (Ong, 1967, p. ix). Could it be, Ong asks, that we have become relatively deaf, that we have adjusted to the post-Newtonian silent universe, and that words that existed in a sensorium have grown utterly strange to us?

\section{Phenomenological writing as a moving beyond}

Within hermeneutic phenomenology, writing is the method; it is how phenomenological research is done (van Manen, 1997b) and it is through language and writing that we can hope to come to understand some aspect of life. Hermeneutic phenomenology is not just a matter of reporting research findings in the conventional way. Here we employ quotes from two scholars to illuminate the difference between a traditional research report and a phenomenological study:

The element of discovery takes place, in non-fiction, not during the writing but during the research. This makes writing a piece very tedious. You already know what it’s about. (Plimpton, 1981, p. 352)

Once one has started to write a paper, it often looks very different from what the raw data suggested to you. Sometimes ... you suddenly find that you are, in fact, espousing quite a different doctrine to what you did when you started writing the paper ... As I write ... I see something in an entirely new light ... The act of writing is ... where you do analyse your data. (Rymer, 1988, p. 239)

The quote from Plimpton highlights two distinct features which distinguish hermeneutic phenomenology from traditional research reports. The first is that we do not separate research from writing. The second is that we do not "already know what it's about." Quite the contrary, we, as Rymer says, analyse the informants' lived-experience descriptions through the act of writing. To enter the world of lived experiences through the world of language is to embark on an adventurous endeavor, which sometimes proves to be an amazing discovery as the meaning of an experience unfolds before our eyes, on paper or on the screen. However, there is an ironic paradox in writing for discovery: we discover nothing at all.

Building on the myth of Orpheus and Eurydice and Blanchot's (1982) interpretation of it, van Manen (2002) describes phenomenological writing as "falling forward into the dark" or as "writing in the dark." It is not uncommon for writers of phenomenological texts, van Manen argues, to find that "every word kills and becomes the death of the object it tries to represent ... language kills whatever it touches ... there is nothing to say ... it is impossible to truly 'say' something” (p. 244). There is, says van Manen "no soaring height to reach from which things could be seen in Heideggerian brightness” (p. 246). The quote, which van Manen most likely 
refers to when he talks about Heideggerian brightness, reads:

Language is - language, speech. Language speaks. If we let ourselves fall into the abyss denoted by this sentence, we do not go tumbling into emptiness. We fall upward, to a height. Its loftiness opens up a depth. The two span a realm in which we would like to become at home, so as to find a residence, a dwelling place for the life of man. (Heidegger, 2001, pp. 189-190)

“Language speaks.” Language always speaks. Not of darkness or of emptiness, but of a realm in which humans dwell. The Heideggerian height symbolizes the space where language is in fact born, employed, and communicated. It lets the things speak and it permits us, as phenomenological writers, to be "bespoken by language” (p. 190).

Even though van Manen's line of thought is well grounded and carefully argued, it does bring to mind a certain linguistic nihilism which implies that language occults the object it strives to represent (e.g., Donato, 1993). To name the project of writing "writing in the dark," which allows neither clear views nor compelling words to be distinguished or verbalized also implicitly, places phenomenological writing in a romantic tradition, in the wake of Plato's world of ideas-where the writer dwells, quite content in his or her subjectivity. To ask of phenomenology that it make anything or everything clear is to remain in the realm of Husserl's transcendental phenomenology, where essence precedes existence. But there is no original meaning, just possible meanings and shadows on the wall of the cave, which we as researchers can try to describe, interpret, and bestow meaning upon. Hermeneutic phenomenology is not a romantic project; it is very much a realistic project. It is an exploration into the lifeworld - the puzzling, the complex, and sometimes the unintelligible world we live in and experiences we live through. The phenomenon is not a meaning but a thing, a substance. Like when we read a poem we attend to what is there, to the very speaking of the substance, for "what the thing is is there," Murdoch (1953) notes. She continues:

The image which suggests itself is that of language as an opaque coagulated substance to be contemplated for itself alone, or else as a transparent glass through which one looks at the world or a tool with which one prods it”. (p. 7172)

The language that is spoken by the things and events of the world is a language that speaks clearly, but if we attend to the world with a phenomenological rather than with a natural attitude (Sokolowski, 2000), language can leave us with “an opaque coagulated substance.” Heidegger, in fact, demonstrates with his awareness of language that phenomenology takes away the transparency of things as well as of language itself. It is of course true, that sometimes the act of writing is a "curling up with language" (Jelinek, 2004), but if we remain curled up with language, the whole phenomenological project, as research on practice, is at jeopardy. To write phenomenology is not a matter of quenching some thirst for poetic writing in the researcher. In that case we would truly be writing in the dark, and the widespread misunderstanding that phenomenology is "anti-scientific, not based upon analysis and description but originating in a kind of uncontrollable intuition or metaphysical revelation” (Schutz, 1979, p. 55) would be a diehard misconception.

Phenomenology does not claim privileged access to truth or accurate insights, nor should we ask of ourselves, as phenomenologists, whether what we unveil is a definite truth. We must, as 
Sartre (1949) argues, give up "the impossible dream of giving an impartial picture of Society and the human condition” (p. 23). Then, and only then, can writing phenomenologically be a strenuous pleasure that challenges the strength of our attention (Weil, 1990), and thus implicates a shared difference in our common existence (Luijpen, 1960) instead of remaining merely the "poet's" personal pain. Only then, can we get out of the grip of "curling up with language" where we see nothing, or simply see through making the world and our lived experiences transparent, invisible, as Lewis (1986) notes:

The whole point of seeing through something is to see something through it. It is good that the window should be transparent, because the street or garden beyond is opaque. How if you saw through the garden too? It is no use trying "to see through" first principles. If you see through everything, then everything is transparent. But a wholly transparent world is an invisible world. To see through all things is the same as not to see. (p. 48)

Phenomenological writing is the practice of going beyond what is immediately apparent by directing attention to the is-ness of what is there. As such, writing phenomenology is the approval of perceptive and linguistic non-transparency. Furthermore, writing is the transitional practice of letting human experience pass beyond the abstract, conceptual, cognitive condition of a traditional scientific practice in order to let experience reverberate immediately beyond everything we think we already know. It is to carefully "touch the depths before it [experience] stirs the surface" (Bachelard, 1994, p. xxiii). Writing phenomenology can never simply be to "iterate what is already given and understood in lived experience in the way that it is given and understood" (Burch, 1989, p. 4). Writing, as a hermeneutic phenomenological endeavor, constantly aims at transcending the natural attitude of things by going beyond their transparent obviousness and "re-achieving a direct and primitive contact with the world" (Merleau-Ponty, 2002, p. vii). For Løgstrup (1971), the natural attitude equals triviality, which is our unreflected way of seeing things. As a contrast to triviality, Løgstrup offers the concept of beauty:

Because triviality is false, unclear, and imprecise, and because beauty overcomes triviality, which otherwise is the atmosphere in which everything is seen. The world, nature, things are brought close to us in a manner which is revelational in character ... It is revelation and nearness; and beauty is so to speak its means in that beauty destroys triviality. (p. 206)

In an expressive (aesthetic) language, Løgstrup also sees a deep ethical commitment when he holds that a beautiful text brings a message from an existence in which we already find ourselves and that expressive writing reveals that "we are blind and deaf to the world in which we live" (p. 218). Thus, phenomenological writing is the interlacing of the ethical and the aesthetic.

When we try to abide by Merleau-Ponty's postulate, we dwell in the space between a poetic attitude, in which the writer has "a silent contact with the things, touching them, testing them, palping them" (Sartre, 1949, p. 14), and a utilitarian writing style in which words are domesticated and honed to express the lived experience. However, we are never quite capable of expressing what we want to say. We say "too much or not enough; each phrase is a wager, a risk assumed” (p. 37). Sartre’s statement could indeed be seen as rather disheartening, but at the same time, it is immensely inspiring; it urges us, forces us, and pushes us to write evocatively of lived experiences - with even more careful circumspection-and deeper devotion. 


\section{Endnotes}

${ }^{1}$ We have borrowed the title from a quote in Ong, W. J. (1967). The presence of the world. New Haven: Yale University Press.

${ }^{2}$ Here we see "poetic" as Heidegger's Dichtung, which has a broader meaning than "poetry". See the side heading Poetic writing or writing poetry?

${ }^{3}$ Some experiential accounts in this article are, if not otherwise stated, drawn from the authors' own lived experiences.

${ }^{4}$ Translated versions from Dutch to English are available in Kockelmans, 1987.

${ }^{5}$ From the Latin in pectore, "in the breast". To do something privately and not announced to the general public.

${ }^{6}$ Van den Berg is writing from a Dutch perspective, thus the date and year.

${ }^{7}$ Dative, from Latin dativus, meaning appropriate to giving.

\section{References}

Abrams, M. H. (1953). The mirror and the lamp: Romantic theory and the critical tradition. Oxford: Oxford University Press

Bachelard, G. (1994). The poetics of space. (M. Jolas, Trans.) Boston: Beacon Press. (Original work published 1958).

Barthes, R. (1981). Camera Lucida: Reflections on photography. (R. Howard, Trans.) New York: Hill and Wang.

Barthes, R. (1989). The rustle of language. (R. Howard, Trans.). Berkeley: University of California Press. (Original work published 1984).

Burch, R. (1989). Phenomenology and its Practices. Phenomenology + Pedagogy, 7, 187-217.

Cooley, C.H. (1902). Samhället och individen. Göteborg: Korpen.

Derrida, J. (1992). On the name. California: Stanford University Press.

Dreyfus, H. (1991). Being-in-the-world. A commentary on Heidegger's being and time. Division Cambridge: Massachusetts University Press.

Donato, E. (1993). The script of decadence: Essays on the fictions of Flaubert and the poetics of romanticism. New York: Oxford University Press.

Gadamer, H.-G. (1985). Truth and method. (G. Barden and J. Cumming, Trans.). New York: Crossroad. (Original work published 1960). 
Gadamer, H.-G. (1976). Philosophical hermeneutics. (D. E. Linge, Trans.). Los Angeles: University of California Press.

Gadamer, H.-G. (2002). The relevance of the beautiful and other essays. (N. Walker, Trans.). Cambridge: Cambridge University Press. (Original work published 1977).

Heidegger, M. (1962). Being and time. (J. Macquarrie \& E. Robinson, Trans.) Oxford: Basil Blackwell. (Original work published 1926).

Heidegger, M. (2001). Poetry, language, thought. (A. Hofstadter, Trans.) New York: Harper \& Row. (Original work published 1971).

Heidegger, M. (1989). Parmenides. Indianapolis: Indiana University Press.

Henriksson, C. (2008). Living away from blessings. School failure as lived experience. London, Ontario: The Althouse Press.

Henriksson, C. (2009). Curriculum in abundance-A phenomenological reading. Journal of the American Association for the Advancement of Curriculum Studies, 5. www.uwstout.edu

Inwood, M. (2006). A Heidegger dictionary. Oxford: Blackwell.

Jelinek, E. (2004). Nobel lecture. Retrieved from www.nobelprize.org

Kockelmans, J.J. (Ed.). (1987). Phenomenological psychology: The Dutch school. Dordrecht: Kluwer.

Kuhns, R. (1970). Structures of experience. Essays on the affinity between philosophy and literature. New York: Basic Books.

Levering, B. \& van Manen, M. (2001). Phenomenological anthropology in the Netherlands and Flanders. In Teresa Tymieniecka (Ed.), Phenomenology world-wide (pp. 274-286). Dordrecht: Kluwer Press.

Lewis, C.S. (1943/1986). The abolition of Man. London: Collins.

Luijpen, W. A. (1960). Existential phenomenology. Pittsburgh: Duquesne University Press.

Løgstrup, K. E. (1971). The ethical demand. (Trans. J. M. Gustafson). Philadelphia: Fortress Press.

Martinsen, B., Harder, I., \& Biering-Sorensen, F. (June 2008). The meaning of assisted feeding for people living with spinal cord injury: a phenomenological study. Journal of Advanced Nursing, Vol. 62(5), 533-540.

Merleau-Ponty, M. (2002). Phenomenology of perception. (C. Smith, Trans.) New York: 
Routeledge. (Original work published 1945).

Merleau-Ponty, M. (1997). The visible and the invisible. (A. Lingis, Trans.). Evanston: Northwestern University Press. (Original work published 1964).

Murdoch, I. (1953). Sartre Romantic Rationalist. Cambridge: Bowes \& Bowes.

Ong, W. J. (1967). The presence of the world. New Haven: Yale University Press.

Online Etymology Dictionary. (2004). Retrieved from www.etymologyonline.com

Plato (1973). The republic and other works. (B. Jowett, Trans.). New York: Anchor Books.

Plimpton, G. (1981). Writers at work. The Paris review interviews. Harmondsworth: Penguin.

Proust, M. (1970). Rememberance of things past. Swann's way. (C. K. S Moncrieff \&T. Kilmartin, Trans.). New York: Vintage Books. (Original work published 1913).

Ricoeur, P. (1998). Hermeneutics \& the human sciences. (J. B. Thompson, Trans.). Cambridge: Cambridge University Press. (Original work published 1981).

Rymer, J. (1988): Scientific composing processes: How eminent scientists write journal articles. In D. A. Jolliffe (Ed.), Advances in writing research, Volume 2: Writing in academic disciplines. Norwood, NJ: Ablex.

Sartre, J-P. (1949). Literature and existentialism. (B. Frechtman, Trans.). New York: Citadel Press. (Original work published 1949).

Sævi, T. (2005). Seeing disability pedagogically. The lived experience of disability in the pedagogical encounter. Bergen: University of Bergen, Norway.

Schutz, A. (1970). On phenomenology and social relations. Chicago: The University of Chicago Press.

Sokolowski, R. (2000). Introduction to phenomenology. Cambridge: Cambridge University Press.

Umrigar, T. (2007). The space between us. London: Harper Perennial.

Van den Berg, J. H. (1961). The changing nature of man. Introduction to a historical psychology. (H. F. Croes, Trans.). New York: Dell Publishing. (Original work published 1956).

Van Manen, M. (1989). By the light of anecdote. Phenomenology+Pedagogy, 7, pp. 232-253.

Van Manen, M. (1997a). From meaning to method. Qualitative Health Research: An International, Interdisciplinary Journal, 7(3), 345-369. 
Van Manen, M. (1997b). Researching lived experience. London, Ontario: The Althouse Press.

Van Manen, M. (2002). Writing in the dark. London, Ontario: The Althouse Press.

Walters, M. (2000). The shape of snakes. London: Macmillan.

Weil, S. (1990). Ordenes makt. Essays i utvalg. Oslo: Solum.

Wivel, O. (1953). Poesi og eksistens. Copenhagen: Gyldendal. 